\title{
Article \\ Evaluation of Vermicompost Produced by Using Post-Consumer Cotton Textile as Carbon Source
}

\author{
Vijaypal Singh, Jordan Wyatt, Ali Zoungrana and Qiuyan Yuan * (D) \\ Department of Civil Engineering, University of Manitoba, Winnipeg, MB R3T 5V6, Canada; \\ singhv1@myumanitoba.ca (V.S.); jbwyatt427@gmail.com (J.W.); zoungson1@gmail.com (A.Z.) \\ * Correspondence: Qiuyan.Yuan@umanitoba.ca
}

Citation: Singh, V.; Wyatt, J.; Zoungrana, A.; Yuan, Q. Evaluation of Vermicompost Produced by Using Post-Consumer Cotton Textile as

Carbon Source. Recycling 2022, 7, 10. https://doi.org/10.3390/

recycling7010010

Academic Editor: Leonel

Jorge Ribeiro Nunes

Received: 8 January 2022

Accepted: 15 February 2022

Published: 21 February 2022

Publisher's Note: MDPI stays neutral with regard to jurisdictional claims in published maps and institutional affiliations.

Copyright: (C) 2022 by the authors. Licensee MDPI, Basel, Switzerland. This article is an open access article distributed under the terms and conditions of the Creative Commons Attribution (CC BY) license (https:// creativecommons.org/licenses/by/ $4.0 /)$.

\begin{abstract}
A large amount of textile waste is generated every year around the globe. The textile product made from natural fibers might be vermicomposted and used as fertilizer. The present study aimed to research an integrated system of pre-composting (pathogen kill) and vermicomposting with various levels of post-consumer cotton waste to determine if this addition has any effects on the composting process. A vermicompost bin was constructed and filled with feedstocks mixed with post-consumer cotton textile waste at a 25:1 C:N ratio, and operated for three months at approximately $70 \%$ moisture content, with four composting trials with $0 \mathrm{~g}$ (control), $100 \mathrm{~g}, 200 \mathrm{~g}$, and $300 \mathrm{~g}$ of textile waste. The precomposting stage reached a temperature ranging from $40{ }^{\circ} \mathrm{C}$ to $50{ }^{\circ} \mathrm{C}$, able to neutralize the pathogens. All four trials resulted in final compost with $\mathrm{C}$ : $\mathrm{N}$ ratios around 14, proving that post-consumer cotton textile waste did not affect the vermicomposting process, and was successfully used as a carbon source by worms to produce a healthy and mature compost. This indicates a sustainable option for the recovery of textile waste that is being decomposed in landfills.
\end{abstract}

Keywords: earthworms; manure; post-consumer cotton; textile waste; vermicomposting

\section{Introduction}

The increasing generation of solid waste is inextricably linked to global population growth and improved standards of living. The increasing growth of the world population results in an increase in textile demand and rising living standards, causing overconsumption due to fast-fashion trends [1,2]. Textile waste is classified into three types, which are production waste, re-consumer waste, and post-consumer waste. Due to the short lifetime of some textile products and fast-fashion trends, post-consumer textile waste, known as discarded solid textile articles which have no more use to the owner, is the most abundant and exhibits a major management concern. From 1960 to 2017, for instance, the yearly amount of post-consumer textile waste generated in the United States has increased nearly tenfold [3]. Textiles Tuesday reported that the average person disposes of $37 \mathrm{~kg}$ of textile waste each year, which 95\% representing $35 \mathrm{~kg}$ could be reused or recycled [4].

Many methods are available to manage post-consumer textile waste, but relevant ones should take into account good practices which emphasize a context of circular economy and integrate lower environmental impact through a proper life cycle assessment. Waste prevention is the best way to manage waste by not producing it at all, this being impossible; minimizing waste production is crucial and could solve a large part of the problem. The minimization of textile waste might be more effective with the application of reuse, recycling, or reclaiming fibers or fabrics of post-consumer textile waste, which are common sustainable processes for textile waste management, environmentally viable, and have a high positive impact on the environment [5-7]. Waste-to-energy is another way of useful management of post-consumer textile waste, which is adequate for the production of thermal energy during its elimination. Landfilling is the final disposal of post-consumer textile waste, but has no benefit and is at the same time harmful. Such waste in a landfill 
can generate $\mathrm{CO}_{2}$ and $\mathrm{CH}_{4}$; consequently, such a method is both an economic loss and a pollution source $[5,7]$. According to Yalcin-Enis et al., $45 \%$ of post-consumer textile waste can be used as secondhand clothing, 30\% can be cut up and used as industrial rags, $20 \%$ can be biodegraded after landfilling, and only $5 \%$ will be unusable [1].

As a cellulosic fiber, cotton is inherently a carbon-rich organic material, theoretically making it compostable. Cotton has the highest cellulose content of any natural fiber, with dried cotton fiber ranging from $88 \%$ to $96 \%$ cellulose. Other components include protein, ash, pectic substances, acids, and wax [8]. Research into bioconversion of postconsumer textile products into usable compost has increased recently [9]. In partnership with Cotton Incorporated, researchers from Cornell University studied the biodegradability of cotton jersey-knit fabrics subjected to various treatments, including scouring, bleaching, treatment with a softener, and treatment with resin. Results showed weight losses from $50-77 \%$ in the cotton samples. It was deemed that all tested treatments of cotton fabric were "compostable" [9].

Composting is a controlled process in which organic material is decomposed to produce humus that can be used as a healthy soil amendment that supplies adequate nutrients and is free of pathogens, not toxic to the plants [10]. Microorganisms are responsible for the biochemical degradation of the materials, converting anything from food waste to soiled paper products into dark brown, damp, spongy humus. Most types of composting are considered aerobic processes, meaning they require oxygen. The inputs of healthy compost include the right balance of carbon-rich $(\mathrm{C})$ and nitrogen-rich $(\mathrm{N})$ materials $(\mathrm{C}: \mathrm{N}$ ratio between 25-40), air, and water [9]. The processing of organic wastes into organic fertilizers via traditional thermophilic composting is a technique that has been used to address the issues of environmental pollution, non-reliance on chemical fertilizers, sustainable natural soil fertility, and minimizing the development of new dumps and landfills. The major problems associated with traditional thermophilic composting are the long duration of the process, the need of reducing the size of the feedstocks to provide the required surface area and the frequent requirement of mixing, loss of nutrients during the prolonged composting process, and the heterogeneous nature of the product [11].

Vermicomposting is a biotechnological process that uses earthworms and microorganisms to convert organic waste into a bio-fertilizer [12,13]. In contrast to traditional thermophilic composting, vermicomposting results in the bioconversion of the waste stream into two useful products: the earthworm biomass and the vermicompost. The former product can further be processed into proteins or high-grade horticultural compost. The latter product (vermicompost/castings) is also considered an excellent product since it is homogenous, has desirable aesthetics, reduced levels of contaminants, and tends to hold more nutrients over a longer period without adversely impacting the environment [14]. For effective production of mature compost, temperature, moisture, aeration, $\mathrm{pH}$, feedstock quality, and $\mathrm{C} / \mathrm{N}$ ratio are important biotic and abiotic factors that influence the vermicomposting process, which can vary depending on the waste type and composition as well as the worm species used $[13,15]$. Suitable values for vermicomposting are generally a moisture content between $60 \%$ and $80 \%$, pH range from 5.5 to 8.5 with an optimum around 7, and an optimal temperature between $12{ }^{\circ} \mathrm{C}$ and $28^{\circ} \mathrm{C}$ for earthworm metabolic activity and reproduction. An appropriate carbon to nitrogen ratio for optimal earthworm digestion is necessary too, but the $\mathrm{C} / \mathrm{N}$ ratio is very variable for different species [15]. The C/N ratio should be adequate between $25 / 1$ and $40 / 1$ for traditional composting, but carbon consumption over time can result in higher nitrogen content [16]. The major drawback in the vermicomposting process is that, in contrast to traditional thermophilic composting (where thermophilic bacteria can raise the material temperature to more than $70^{\circ} \mathrm{C}$ ), the vermicomposting processes must be maintained at temperatures below $35^{\circ} \mathrm{C}$ [14]. Exposure of worms to temperatures above this will kill them. The vermicomposting process temperature is therefore not high enough for acceptable pathogen kill, and, hence, the product does not pass EPA rules for pathogen reduction. However, it is required that (US-EPAs 40 CFR Part 503) temperatures reach (a) $40{ }^{\circ} \mathrm{C}$ for at least five consecutive 
days and $55{ }^{\circ} \mathrm{C}$ for at least three consecutive days, or alternatively (b) temperatures of $55^{\circ} \mathrm{C}$ are maintained for at least three consecutive days in the coolest part of compost undergoing aeration [17].

An integrated system approach that begins with traditional thermophilic composting as a pretreatment step to ensure pathogen kill followed by the vermicomposting process would be necessary to provide a product free of pathogens, with desirable characteristics, at a faster composting rate than either of the individual processes. The resulting compost is expected to be of high quality but also cheaper to produce if composting and curing time is effectively reduced [14]. The present study investigated the feasibility of vermicomposting on post-consumer cotton waste to test an integrated system of pre-composting (pathogen kill) and vermicomposting with varying levels of post-consumer cotton waste to determine if this addition has any effects on the composting process (specifically time required) and the grade of the end product.

\section{Materials and Methods}

\subsection{Compost Vessel}

A plastic container with a volume of $85.157 \mathrm{~L}$ ( $67 \mathrm{~cm}$ length, $41 \mathrm{~cm}$ width, and $31 \mathrm{~cm}$ depth) was used for the composting experiments. Holes were drilled in the bottom of each container to allow excess water to drain from the bottom of the compost and prevent the development of "humid" conditions with the composting vessel. Each vessel was insulated with approximately $10 \mathrm{~cm}$ thickness fiberglass insulation on all sides to prevent heat loss during the traditional thermophilic pre-composting phase. The composting vessel scheme and image can be seen below in Figure 1.

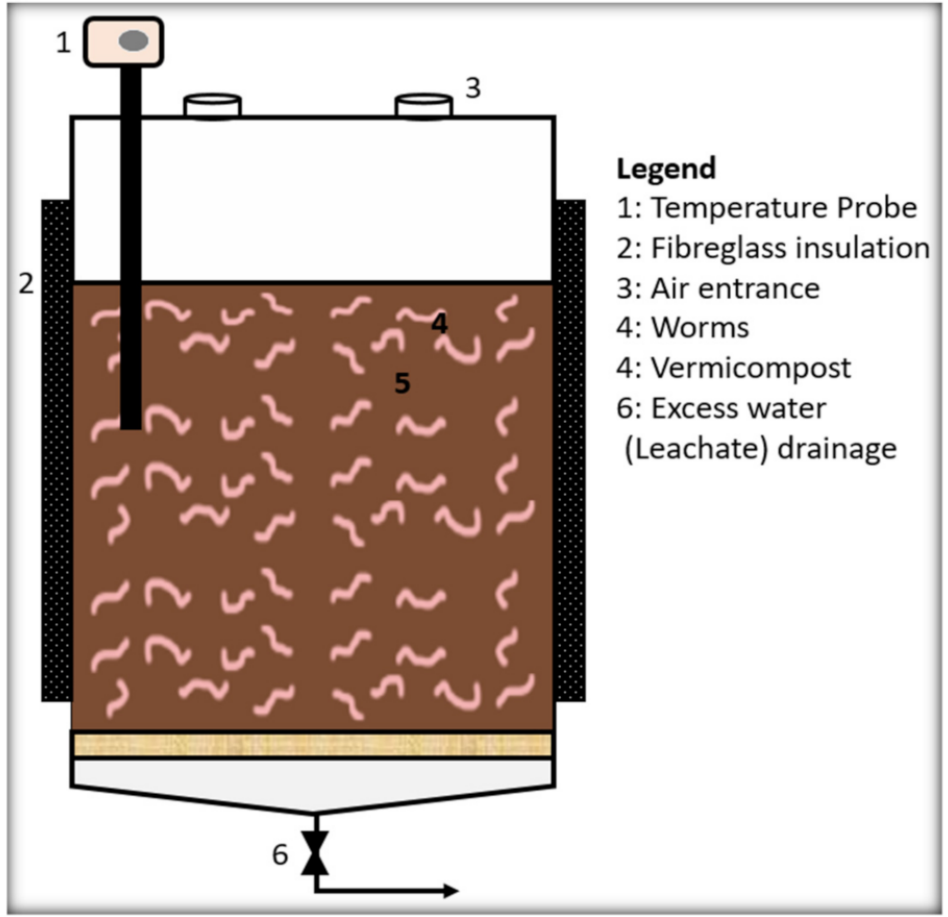

(a)

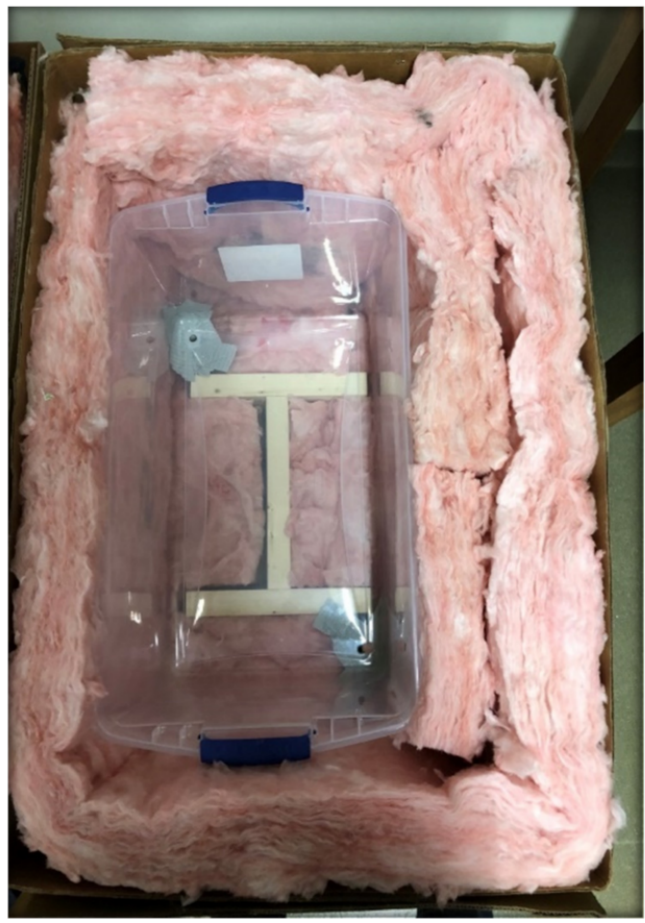

(b)

Figure 1. Composting vessel used during the experiment; (a) Scheme (left), (b) Image.

\subsection{Composition of the Composting Materials and Different Levels of Post-Consumer Cotton Waste Mixture}

The overall experiment consisted of four separate composting trials with varying levels of post-consumer cotton textile waste added. Each trial would undergo a pre-composting phase followed by a vermicomposting phase. The compost would consist of the following constituents with content parameters, as shown in Table 1. Appropriate amounts of each 
constituent for each trial were calculated to maintain a 25:1 C: $\mathrm{N}$ ratio and a feed depth of $20-25 \mathrm{~cm}$. The values for each trial are summarized in Table 2. Nitrogen content and moisture content were similar in all trials with the components depicted in Table 3.

Table 1. Compost constituent parameters.

\begin{tabular}{ccccc}
\hline Feed Stock & Moisture (\%) & Carbon Content (\%) & Nitrogen Content (\%) & $\begin{array}{c}\text { Density } \\
(\mathbf{k g} / \mathbf{L})\end{array}$ \\
\hline Leaves & 38.3 & 48.6 & 1.2 & 0.25 \\
Biosolids & 69.8 & 27.6 & 3.6 & 0.58 \\
Sawdust & 32.8 & 49.7 & 0.6 & 0.3 \\
Cotton & 8.1 & 43.6 & 0.3 & 0.3 \\
Water & 100 & 0 & 0 & 1 \\
\hline
\end{tabular}

Table 2. Compost trial composition.

\begin{tabular}{|c|c|c|c|c|c|c|c|c|}
\hline & \multicolumn{2}{|c|}{ Trial 1-Control } & \multicolumn{2}{|c|}{ Trial 2} & \multicolumn{2}{|c|}{ Trial 3} & \multicolumn{2}{|c|}{ Trial 4} \\
\hline Feed Stock & Weight (kg) & $\begin{array}{c}\text { Carbon } \\
\text { Content } \\
(\mathrm{kg})\end{array}$ & Weight (kg) & $\begin{array}{l}\text { Carbon } \\
\text { Content } \\
\text { (kg) }\end{array}$ & Weight (kg) & $\begin{array}{l}\text { Carbon } \\
\text { Content } \\
\text { (kg) }\end{array}$ & $\begin{array}{l}\text { Weight } \\
\text { (kg) }\end{array}$ & $\begin{array}{c}\text { Carbon } \\
\text { Content } \\
(\mathrm{kg})\end{array}$ \\
\hline Leaves & 4.50 & 2.19 & 4.40 & 2.14 & 4.30 & 2.09 & 4.20 & 2.04 \\
\hline Biosolids & 7.52 & 2.07 & 7.52 & 2.07 & 7.52 & 2.07 & 7.52 & 2.07 \\
\hline Sawdust & 11.25 & 5.59 & 11.25 & 5.59 & 11.25 & 5.59 & 11.25 & 5.59 \\
\hline Cotton & - & - & 0.10 & 0.04 & 0.20 & 0.09 & 0.30 & 0.13 \\
\hline Water & 5.00 & - & 5.00 & - & 5.00 & - & 5.00 & - \\
\hline Total & 28.27 & 9.85 & 28.27 & 9.85 & 28.27 & 9.84 & 28.27 & 9.84 \\
\hline
\end{tabular}

Table 3. Composition of nitrogen and moisture content.

\begin{tabular}{ccc}
\hline Feed Stock & Moisture Content $\mathbf{( k g )}$ & Nitrogen Content $\mathbf{( k g )}$ \\
\hline Leaves & 1.72 & 0.05 \\
Biosolids & 5.25 & 0.27 \\
Sawdust & 3.69 & 0.07 \\
Cotton & - & - \\
Water & 5.00 & - \\
Total & 15.66 & 0.39 \\
\hline
\end{tabular}

\subsection{Composting Process}

The textile waste was prepared for composting by blending into fine strands to improve the compostability, Figure 2a. The different composting materials were then measured with a laboratory scale and added to the composting vessels according to the values of the designed trials, as mentioned above, Figure $2 b$. During the initial pre-composting phase of 4 weeks, containers were kept sealed in an attempt to retain as much heat as possible, and the compost was turned every four days to ensure even exposure. During this process, the temperature was monitored, and the moisture was maintained at approximately $70 \%$. Following the pre-composting phase, the vessels were unsealed, and a mixture of juveniles and adults Eisenia fetida (earthworms) supplied from a local seller (Winnipeg, Canada) were added to the compost mixture at a stocking density of $0.5 \mathrm{~kg} / \mathrm{m}^{2}$ for vermicomposting. The earthworms were not acclimatized before the experiment. The vermicomposting phase lasted three months during which the mixtures were turned every 15 days to ensure even exposure. The composting temperature with Eisenia fetida is reported to be between $15-25{ }^{\circ} \mathrm{C}$ and the performance increases with temperature up to $25^{\circ} \mathrm{C}[18,19]$, while moisture content was recommended between $60-75 \%[18,20]$. The present study was investigated at an average temperature of approximately $20{ }^{\circ} \mathrm{C}$ and moisture around $70 \%$, following the optimal vermicomposting conditions reported in the literature. 


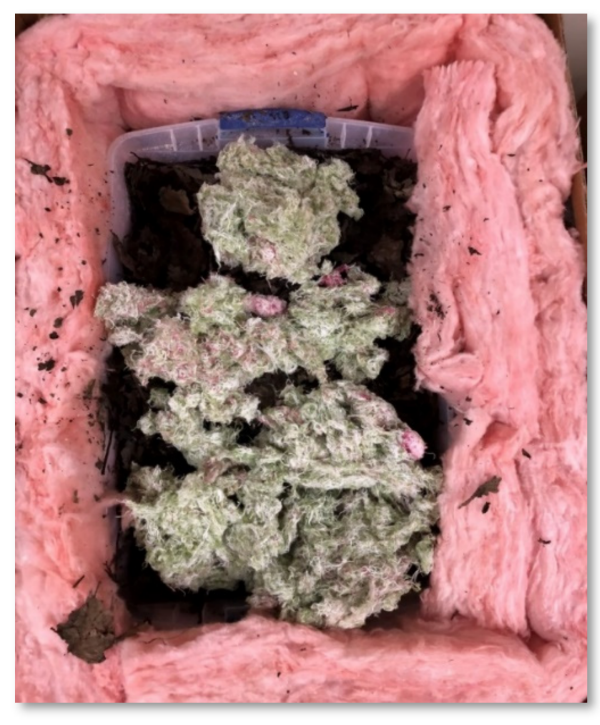

(a)

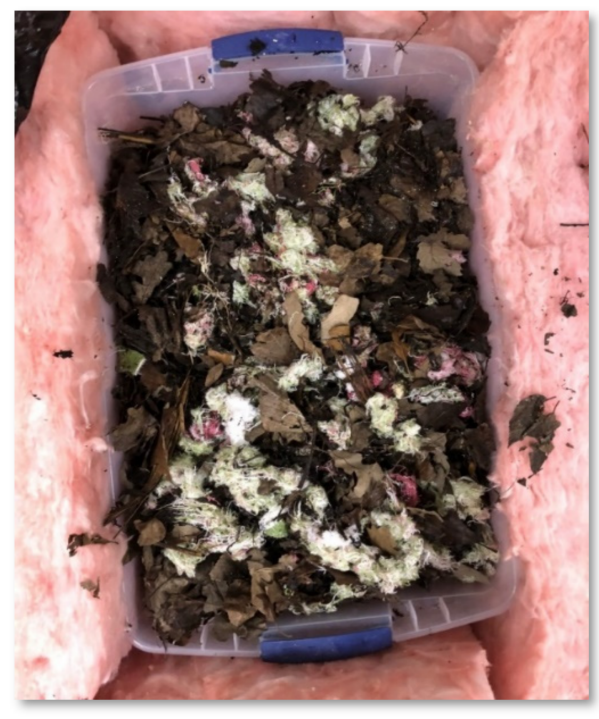

(b)

Figure 2. (a) Blended cotton waste ready to be mixed (left), (b) mixed cotton waste with composting materials (right).

\section{Results and Discussion}

\subsection{Pre-Compost Phase}

The pre-compost phase consisted of traditional composting, the purpose of which is to reach a composting temperature for pathogen neutralization. The temperature was measured during this phase and plotted versus time, as shown in Figure 3. The initial temperature was low and remained steady around $20^{\circ} \mathrm{C}$ for almost a one-week period of the composting process and suddenly increased to a peak value between 40 and $50{ }^{\circ} \mathrm{C}$ for the four trials. After 3 days of peak values, the temperature decreased slowly but remained high around $40{ }^{\circ} \mathrm{C}$ for almost 10 days before gradually falling overtime to $22{ }^{\circ} \mathrm{C}$ at the end of day 30 of the pre-composting process. During the process, the temperature probe was replaced due to malfunction, which may have missed higher temperature values of the composting process; however, the temperatures achieved were encouraging and showed that the addition of post-consumer cotton textile waste did not negatively affect this stage of the process. Additionally, a visual inspection of the compost during this phase showed large particles of individual constituents (e.g., leaves), indicating that the composting process was not complete. The results obtained at the end of the pre-composting process demonstrated that the composting waste had achieved partial stabilization. The major issues with single traditional thermophilic composting are the long duration of the process, the frequency with which the material is turned, the need for the material to be reduced in size to provide the required surface area, the loss of nutrients during the prolonged composting process, and the heterogeneous nature of the product [11]. In fact, in addition to achieving the desired temperature for composting, pre-composting would have the advantage of accelerating the vermicomposting process by making the waste readily biodegradable [21]. For many various solid wastes, this phase does not last long, usually taking 5 to 10 days for their completion, but cotton wastes require longer periods from 20 to 25 days or more for their decomposition [22]. 


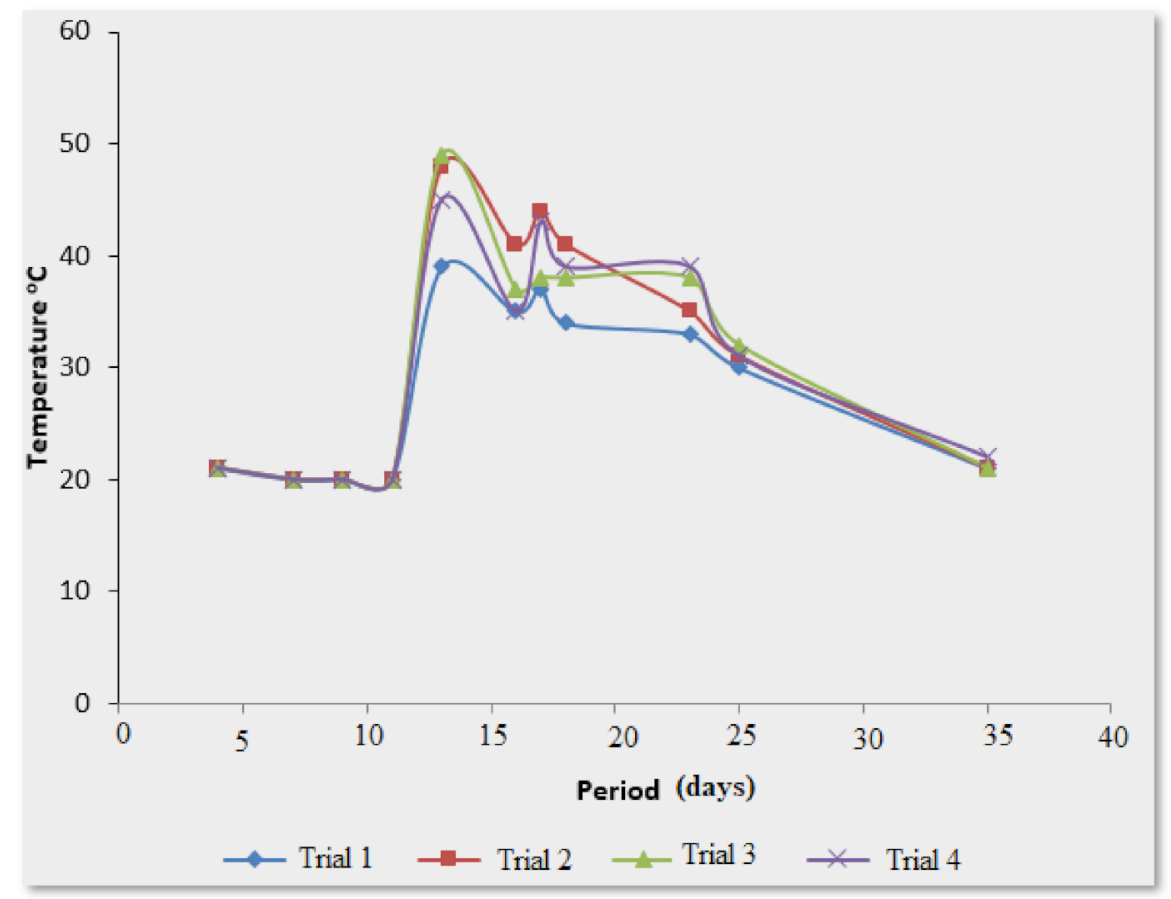

Figure 3. Pre-compost phase temperature vs. time.

\subsection{Vermicomposting Phase}

In vermicomposting, which is a bioconversion process that is widely used in solid waste management, earthworms feed on organic waste, producing more earthworms, vermicompost, and vermiwash as a byproduct [12]. After the pre-compost phase was achieved, the process continued with the vermicomposting phase to determine if differences in compost quality could be observed between the various trials. Therefore, the vessels were unsealed, allowed to cool to room temperature, and the earthworms for vermicomposting were added. Due to the availability, an optimum stocking density of $1.6 \mathrm{~kg}$ earthworms $/ \mathrm{m}^{2}$ of surface area could not be achieved, and the vermicomposting process would require longer to run through to completion. For approximately three months, the process was allowed to continue with biweekly turning (mixing) and maintained a moisture content of approximately $70 \%$. Visual inspection of the compost showed that individual constituents (leaves, cotton, etc.) became unrecognizable as the process continued, turning into a more homogenous mixture with finer particles. Additionally, even though visual observation might not be accurate, it could be seen in all four trials that the earthworm population increased significantly, indicating that the constituents added were creating an environment in which they could thrive, as shown by Figure 4 below. The temperatures were similar for all the trials, around $20^{\circ} \mathrm{C}$ during the vermicomposting, allowing better reproduction and growth of the earthworms [21]. During this phase, the earthworms mineralized the waste and converted a portion of it into worm biomass, while the remainder was ingested as nutrient-rich vermicompost [23]. As the worms can enhance the rate of decomposition of organic materials by fragmenting the substrate material and by providing more casts (the fecal material) with high microbial activity, using vermicomposting as a post-process of traditional composting has an important benefit since the required temperature for ensuring adequate pathogen kill would be achieved during the traditional composting phase [14]. 


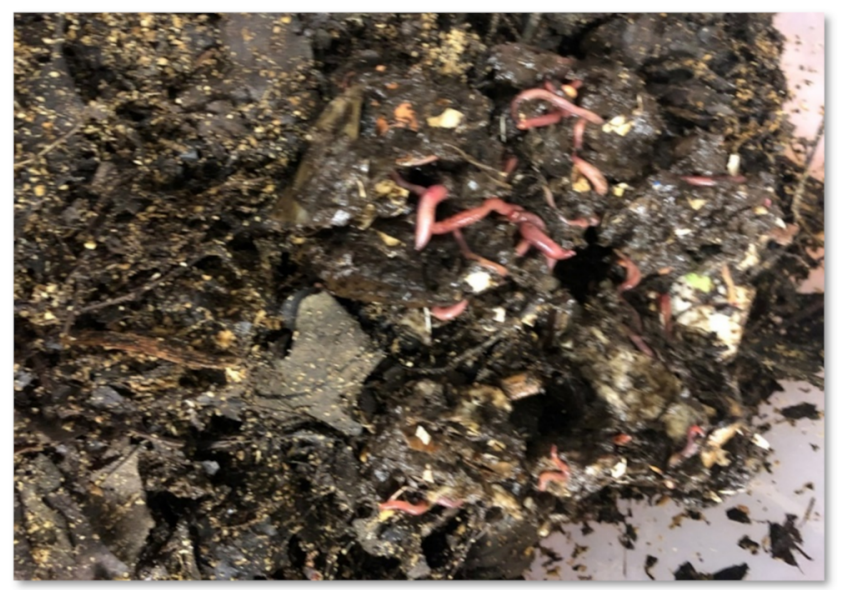

Figure 4. Vermicompost displaying the increased number of worms.

\subsection{Final Compost}

Following the vermicomposting phase of the experiment, the final mature compost of each trial was visually inspected and each was seen to be similar, with fine homogenous particles and no visible individual constituents (leaves, cotton, etc.), as depicted by Figure 5 . C: $N$ ratios of the final compost were measured, and the results can be seen in Table 4 below. The ratios were close to one another and ranged between 14 and 15 . The $\mathrm{C} / \mathrm{N}$ ratio of mature compost depends upon the quality and characteristics of the raw organic waste used, but it is generally about 15 to 20:1 for good and mature compost [22]. The $\mathrm{C} / \mathrm{N}$ ratios for all the trials were similar and in the acceptable range. The ratio was not affected by the addition of post-consumer cotton waste into the composting materials. The similarity of these measurements would indicate that the final compost produced by each trial was similar in quality and that the various amounts of post-consumer cotton textile waste had little impact on the end quality of the compost. It also indicates that worms are able to survive by using cotton textile as a carbon source and they produced healthy and mature compost. Because earthworm digestive secretions aid in the breakdown of soil and organic matter, the earthworm castings contain more nutrients that are immediately available to plants. The produced vermicompost was similar to traditional compost and can be used in the same way in agriculture, on gardens, lawns, and potted plants [22].

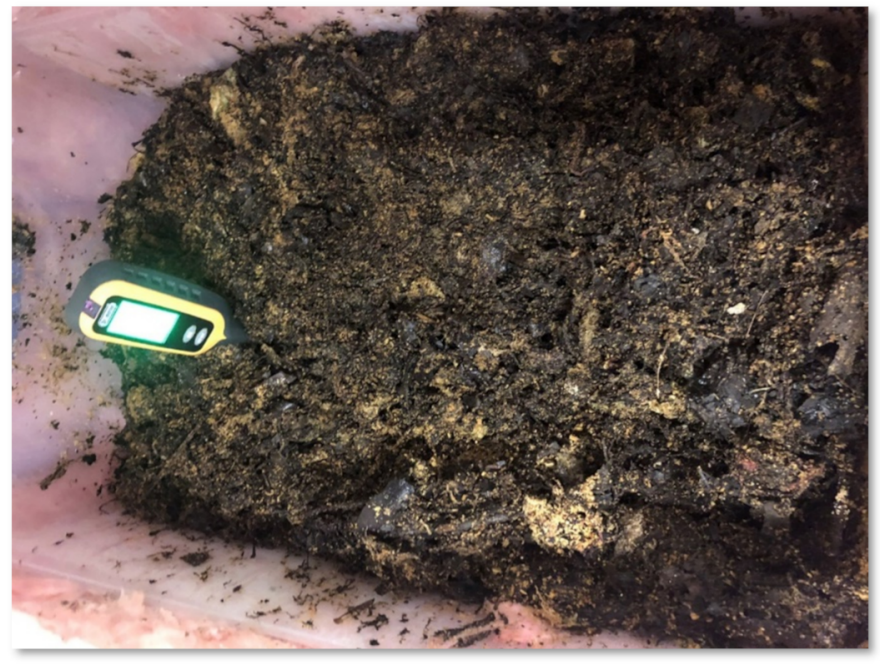

Figure 5. Final mature compost. 
Table 4. C: $\mathrm{N}$ of the final vermicompost product.

\begin{tabular}{cc}
\hline Sample ID & C/N ratio \\
\hline Trial 1 & 14.5 \\
Trial 2 & 13.7 \\
Trial 3 & 14.3 \\
Trial 4 & 15.6 \\
\hline
\end{tabular}

\subsection{Various Post-Consumer Textile Waste Ratio Effect on Vermicomposting Efficiency}

Four trials with different amounts of the cotton waste mixture were used as vermicomposting materials. The process was operated with four composting trials with $0 \mathrm{~g}$ used as control, $100 \mathrm{~g}, 200 \mathrm{~g}$, and $300 \mathrm{~g}$ of post-consumer cotton textile waste. The results depicted similar vermicomposting performance and final compost quality between trial 1 (no mixture of cotton waste) and the three other trials. Achieving similar composting results and compost characteristics suggest that cotton waste is as well compostable as the other materials and the increasing ratio of up to $1 \%(300 \mathrm{~g})$ of the waste weight did not induce any negative impact on the composting process. Castillo-González et al. conducted similar research with the mixture of corn cob waste with various vegetable waste and eggshells at different proportions and reported a stable compost where the load material (vegetable waste and eggshells) balanced the nutrients of the substrate [21], in contrast to most studies using animal manure during the composting of difficult biodegradable materials such as corn cob waste or cotton waste used in our study. Cotton, as a cellulosic fiber, is inherently a carbon-rich organic material, making it compostable. It has the highest cellulose content of any natural fiber, with dried cotton fiber containing between $88 \%$ and $96 \%$ cellulose. Protein, ash, pectic substances, acids, and wax are also present in cotton [8]. This constituent of the cotton, therefore the post-consumer cotton waste, makes it suitable for vermicomposting when mixed with other readily biodegradable materials at an appropriate rate.

\section{Conclusions}

The present study confirmed that an integrated system of pre-composting with traditional thermophilic composting methods followed by a treatment of vermicomposting for compost consisting of a combination of yard waste and bio-solids was not significantly affected by the addition of post-consumer cotton textiles at various low concentrations. The produced compost showed a C:N ratio between 14 and 15 and was similar for all the trials regardless of the presence or not of post-consumer cotton textiles waste. As a result, with pre-composting phase temperature reaching $50^{\circ} \mathrm{C}$, this system has the potential to produce a compost free of pathogens and with desirable characteristics at a faster rate than either of the individual processes, while successfully eliminating potential post-consumer waste streams. The post-consumer textile was successfully used as a carbon source by worms to produce healthy and mature compost. This indicates a sustainable option for the decomposition of textile waste that is being decomposed in landfills. However, it is recommended that further testing be carried out to determine an optimal threshold of cotton content to maximize waste reduction potential while still achieving a high-quality final product.

Author Contributions: Conceptualization, Q.Y.; methodology, V.S. and J.W.; formal analysis, V.S.; investigation, V.S. and J.W.; data curation, V.S. and J.W.; writing—review and editing, Q.Y. and A.Z.; supervision, Q.Y. All authors have read and agreed to the published version of the manuscript.

Funding: This research received no external funding.

Institutional Review Board Statement: Not applicable.

Informed Consent Statement: Not applicable. 
Data Availability Statement: The data presented in this study are available on request from the corresponding author.

Conflicts of Interest: The authors declare no conflict of interest.

\section{References}

1. Yalcin-Enis, I.; Kucukali-Ozturk, M.; Sezgin, H. Risks and Management of Textile Waste. In Nanoscience and Biotechnology for Environmental Applications; Springer: Cham, Switzerland, 2019; pp. 29-53. [CrossRef]

2. Pensupa, N.; Leu, S.Y.; Hu, Y.; Du, C.; Liu, H.; Jing, H.; Wang, H.; Lin, C.S.K. Recent Trends in Sustainable Textile Waste Recycling Methods: Current Situation and Future Prospects. Top. Curr. Chem. 2017, 375, 189-228. [CrossRef]

3. DeVoy, J.E.; Congiusta, E.; Lundberg, D.J.; Findeisen, S.; Bhattacharya, S. Post-Consumer textile waste and disposal: Differences by socioeconomic, demographic, and retail factors. Waste Manag. 2021, 136, 303-309. [CrossRef] [PubMed]

4. Tuesday, T. Waste Reduction Week in Canada. Available online: https://wrwcanada.com/en/theme-days/textiles-tuesday (accessed on 14 December 2021).

5. Gamberini, R.; Galloni, L.; Rimini, B.; Luppi, M. Post-consumer textile waste re-use: Main steps of a sustainable process. In Proceedings of the XIX Summer School "Francesco Turco", Senigallia, AN, Italy, 9-12 September 2014; pp. 354-359.

6. Coskun, G.; Basaran, F.N. Post-Consumer Textile Waste Minimization: A Review. J. Strateg. Res. Soc. Sci. 2019, 5, 1-18. [CrossRef]

7. Stanescu, M.D. State of the art of post-consumer textile waste upcycling to reach the zero waste milestone. Environ. Sci. Pollut. Res. 2021, 28, 14253-14270. [CrossRef] [PubMed]

8. Zhang, X. (Chemical Engineer) Fundamentals of Fiber Science; DEStech Publications, Inc.: Lancaster, PA, USA, $2014 ;$ p. 415. ISBN 1605951196.

9. Gershuny, G. Compost, Vermicompost and Compost Tea: Feeding the Soil on the Organic Farm; Chelsea Green Pub: White River Junction, VT, USA, 2011.

10. Zhang, H.; Li, J.; Zhang, Y.; Huang, K. Quality of vermicompost and microbial community diversity affected by the contrasting temperature during vermicomposting of dewatered sludge. Int. J. Environ. Res. Public Health 2020, 17, 1748. [CrossRef] [PubMed]

11. Papadimitriou, E.K.; Balis, C. Comparative study of parameters to evaluate and monitor the rate of a composting process. Compost Sci. Util. 1996, 4, 52-61. [CrossRef]

12. Manyuchi, M.; Phiri, A. Vermicomposting in Solid Waste Management: A Review. Int. J. Sci. Eng. Technol. 2013, 2, 1234-1242.

13. Sharma, K.; Garg, V.K. Vermicomposting of Waste: A Zero-Waste Approach for Waste Management; Elsevier B.V.: Amsterdam, The Netherlands, 2019; ISBN 9780444642004.

14. Ndegwa, P.M.; Thompson, S.A. Effects of C-to-N ratio on vermicomposting of biosolids. Bioresour. Technol. 2000, 75, 7-12. [CrossRef]

15. Rorat, A.; Vandenbulcke, F. Earthworms Converting Domestic and food Industry Wastes into Biofertilizer; Elsevier Inc.: Amsterdam, The Netherlands, 2019; ISBN 9780128159071.

16. Elcik, H.; Zoungrana, A.; Bekaraki, N. Investigation of Aerobic Compostability of Municipal Solid Waste in Istanbul. Sigma J. Eng. Nat. Sci. 2016, 34, 211-220.

17. Hay, C. Pathogen destruction and biosolids composting. Biocycle 1996, 37, 67-76.

18. Ndukwe, I.; Yuan, Q. Drywall (Gyproc plasterboard) recycling and reuse as a compost-bulking agent in Canada and North America: A review. Recycling 2016, 1, 311. [CrossRef]

19. Ghorbani, M.; Sabour, M.R.; Bidabadi, M. Vermicomposting Smart Closed Reactor Design and Performance Assessment by Using Sewage Sludge. Waste Biomass Valorization 2021, 12, 6177-6190. [CrossRef]

20. Aira, M.; Monroy, F.; Domínguez, J. Microbial Ecology Eisenia fetida (Oligochaeta: Lumbricidae) Modifies the Structure and Physiological Capabilities of Microbial Communities Improving Carbon Mineralization During Vermicomposting of Pig Manure. Microb. Ecol. 2007, 54, 662-671. [CrossRef] [PubMed]

21. Castillo-González, E.; De Medina-Salas, L.; Giraldi-Díaz, M.R.; Sánchez-Noguez, C. Vermicomposting: A valorization alternative for corn cob waste. Appl. Sci. 2021, 11, 5692. [CrossRef]

22. Punde, B.D.; Ganorkar, R.A. Vermicomposting-Recycling Waste into Valuable Organic Fertilizer. Int. J. Eng. Res. Appl. 2012, 2, 2342-2347.

23. Arumugam, K.; Ganesan, S.; Muthunarayanan, V.; Vivek, S.; Sugumar, S.; Munusamy, V. Potentiality of Eisenia fetida to degrade disposable paper cups-An ecofriendly solution to solid waste pollution. Environ. Sci. Pollut. Res. 2015, 22, 2868-2876. [CrossRef] [PubMed] 